\title{
Requests Politeness Strategies in Algerian Learners of English Academic Emails
}

\begin{abstract}
:
How politeness is perceived in different languages and cultures is still a matter of controversy among linguists. There seems to be little agreement on what is polite/impolite in different languages and cultures. The situation is even more aggravated when it comes to foreign language learners. Because of their reliance on their native language/culture sociopragmatic and pragmalinguistic knowledge, many of them transfer their first language rules of politeness into the foreign language. This article is an attempt to examine the Algerian advanced learners of English notions of (in)directness strategies and politeness in the speech act of requests and to demonstrate that many of them fuse their native politeness conventions with those of English. This is mainly attempted through the analysis of their academic emails to their supervisors. The results showed that there is a correlation between complexity/simplicity of request strategies and the learners' level of language proficiency and that the learners' perception of politeness is influenced by their culture.
\end{abstract}

Keywords: Pragmatics, politeness, speech act, culture, request, email, linguistic proficiency.

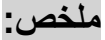

تهدف هذه الدراسة الدلالية إلى استقصاء و وصف استر اتيجيات

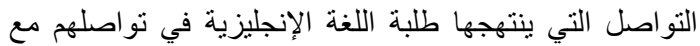

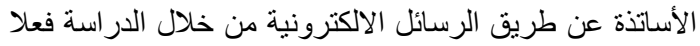

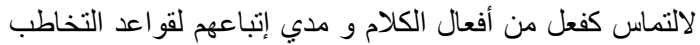
المتفرعة من مبدأ التأدب المعدول بها لإي الدام الناطقين الأصليين

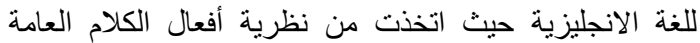

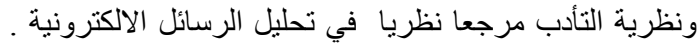

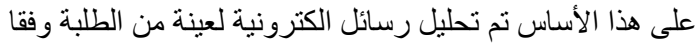

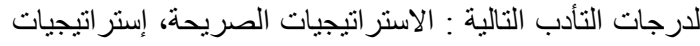

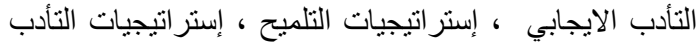

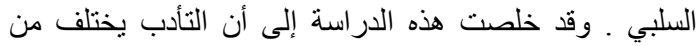

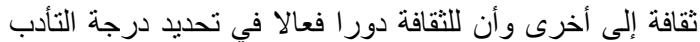

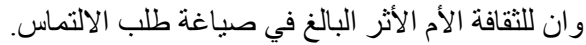

\section{Introduction :}

The use of electronic email has won a wide currency among university students and staff members.It has become an effective medium of communication be it for exchanging or distributing information. As one type of speech acts that often occurs in email communications, requests are an important daily social practice of people through which they seek to enhance social relationships. However, making a request is culture bound. Cultures differ significantly 
in interaction patterns and norms. Each culture has its own ways of making requests, its own ways of perceiving politeness in requests and, most important of all, its own politeness strategies. Consequently, contextual factors such as speaker/hearer social status and social distance as well as the perception of other factors like imposition, obligation and right provide important insights into the sociocultural values and norms that govern the daily life within a given speech community.

The aim of this study is to examine the ways in which the Algerian advanced learners of Englishperform the request speech act, with particular attention to their request perspective, the politeness strategies they adopt and the social variables that affect their requests realization. It mainly seeks to show that the learners' cultural background and linguistic proficiency level influence their requests strategies and perspective.

\section{Literature Review}

Ever since the introduction of the concept of communicative competence by Hymes (1971), the idea that linguistic structure and social structure work together in communication has been reflected most specifically in the concept of the speech act. Different linguists have realised that a linguistic form can be used in different situations to realise different communicative functions. Additionally, the socio-pragmatic rules of language have come to be seen as a device that regulates the use of different linguistic forms in different social situations. Even more important, the views that speech acts differ cross-culturally and that culture can be used as a variable to explain differences in language use are also established as facts. As a result, many scholars became interested in the study of speech acts with the aim to provide a better understanding and new insights into the correlation between linguistic forms and socio-cultural context (Olshtain and Cohen, 1983).

Following these interests, the study of language in use saw significant development in pragmatics studies. Among these developments is the Speech Act Theory. Very briefly, the Speech Act Theory, now seen as a sub discipline of cross-cultural pragmatics, tries to explain how language users achieve intended actions and how hearers deduce intended meanings from what is said.

Prior to the advent of the speech act theory, language was viewed primarily as a way of making factual assertions and that the study of sentence meaning was reduced to a mere description of the fact or state of affairs to which a sentence refers. With the advent of socio-pragmatics, many linguists and philosophers started to analyse meaning in terms of the interrelationships and correlations between the linguistic rules, the situation where an interaction between a speaker and a hearer occurs and the intentions of the speaker. 
Among these scholars, Austin (1962) was by no means the first to deal with the study of speech acts. His series of speeches (lectures) given in 1955 were later on published in a book entitled 'How to Do Things with Words.' His theory, which became to be known as the Speech Act Theory, holds that people 'do more things with words', that is, to perform actions such as apologizing, complimenting, requesting...etc. than simply communicating information. According to Austin (1962), communication is a series of communicative acts or speech acts. A speech act, in his view, is the minimum functional unit in communication such as making statements, giving commands, asking questions or making requests (Austin, 1962). It is an action performed by means of language and defined with reference to the intentions of a speaker at the moment of speaking and the effects it has on a listener (Crystal, 1993). Following Austin (op.cit), a single speech act actually contains three separate but related speech acts: locutionary act: performing an act of saying something, illocutionary act: performing an act in saying something and perlocutionary act: performing an act by saying something. To illustrate the difference between the three concepts, the following example may help: The room is dirty.

The surface form, the locutionary act, of this utterance is a statement describing a state of affairs in a particular situation, i.e. the literal meaning of the utterance. The illocutionary act expresses an indirect request on the part of the speaker, i.e., the function that the utterance performs in the social context. The perlocutionary act expresses the speaker's desire that the hearer cleans the room, i.e., the result or effect produced by the utterance in the given context (Austin, 1962). Among these, the central component of language functions, according to him, is the illocutionary act. A similar view is expressed by Yule (1996, p.49) who affirms, “...the term speech act is generally interpreted quite narrowly to mean only the illocutionary force of an utterance".

Drawing on Austin (1962), one single utterance may have more than one illocutionary force. Take the following: It is hot in here. This utterance in the form of a statement describing some state of affairs, namely that the weather is hot, can be interpreted to mean two different things. It can be interpreted as a request to open the window when uttered by a speaker who does not feel at ease because of the heat, or as an offer to open the window to make others at ease. This utterance has two illocutionary forces. One is direct and the other is indirect. Hence speech acts are of two types: direct and indirect speech acts (Searle, 1975).With an indirect speech act, a speaker can communicate to her/ his interlocutor more than what he actually says and on the basis of shared background knowledge the hearer can infer what the speaker means. At times, Searle (1969) believes, speakers are not very explicit.

Extending Grice's work, Leech (1983) sets the 'Politeness Principle' and claims that it is necessary to maintain good relations. His conception of 
politeness runs as follows: the participants' ability to engage in interaction in an atmosphere of relative harmony. It enables participants in interaction to avoid disruption and to maintain the social equilibrium and friendly relations. Leech assumes that the Politeness Principle ensures that interactants behave politely to one another since they respect each other's 'face'. His principle requires interactants to adopt two strategies: 'Do not offend others' and 'Be nice to others'. Leech (1983: 132) also identifies six maxims associated with politeness. These can be boiled down to:

$>$ Tact maxim: minimise cost to other; maximise benefit to other.

$>$ Generosity maxim: minimise benefit to self; maximise cost to self.

$>$ Approbation maxim: minimise dispraise of other; maximise praise of other.

$>$ Modesty maxim: minimise praise of self; maximise dispraise of self.

$>$ Agreement maxim: minimise disagreement between self and other; maximise agreement between self and other.

> Sympathy maxim: minimise antipathy between self and other; maximise sympathy between self and other.

Despite the criticism directed to Leech's framework of politeness, it is still a suitable approach to compare cross-cultural differences in the use of politeness strategies in certain context (Thomas, 1995). Leech (1983, p.11) believes that the "the Politeness Principle operates variably in different cultures or language communities, in different social situations, among different social classes ...etc."

The most outstanding model of politeness is that developed by Brown and Levinson (1987). Politeness, in their view, is a strategy used by interactants to avoid conflict. Its basic role is in its ability to function as a way of controlling possible aggression between interactants. The central concept within this model of politeness is that of face; a concept coined by Goffman (1959) in the late fifties. This concept is defined to mean "the public self-image that every member wants to claim for himself" (Brown and Levinson, 1987, p. 61). They further argue that "face is something that is emotionally invested, and that can be lost, maintained or enhanced, and must be constantly attended to in interaction" (Ibid).These definitions imply that in a conversation, interactants need to save one's own and others' face. The authors of this theory assume that several universal factors come into play with regard to politeness conventions. They also assume that when the interactants engage in communication, 'face work' comes into play, i.e. the efforts made by the participants to preserve their 
face or to communicate a positive face. Consequently, each of the participants shows two types of face; one is related to an individual's desire not to be imposed on and the other is related to an individual's desire to be liked. The first is referred to in literature as negative face and the second as positive face. Positive face refers to an individual's desire to be appreciated in social interaction and negative face refers to an individual's desire to be free from imposition and to have freedom of action. The theory assumes that in social interaction, participants perform different speech acts some of which are facethreatening. They can be face threatening to both speakers and hearers. It is precisely with face threatening acts that politeness is involved by redressing them.

Following Brown and Levinson (1987), four politeness strategies are proposed to minimize face-threatening acts: bald on record, positive politeness, negative politeness, and off-record indirect strategy. These strategies could be summarized into the following:

i. Bald-an-record: The requester takes no redressive action to minimise the threat to the requestee's face and tends to perform the act in a clear unequivocal way, i.e., a straight way of saying things. The requester is relevant, brief, clear and precise.

ii. Positive politeness: The requester here mitigates the threat by minimising distance, expression of friendliness and recognition of the requestee's desire to be respected, i.e., an expression of solidarity

iii. Negative politeness: the requester avoids coercion and gives the requestee freedom not to do what is requested.

iv. Off-record indirect strategy: Here the requester uses utterances which lend themselves to various interpretations to give the requestee the chance to interpret them as requests or otherwise. Violation of the one of the maxims of the cooperative principle is very apparent. The use of hints, metaphors are examples of off-record indirect strategy.

The choice of one of the above-mentioned strategies in a given event depends on the potential weightiness of the face threat and the interlocutors' social distance, relative power, and size of the imposition. These social factors determine the level of politeness (Brown and Levinson, 1987). They assume that the increase in politeness is commensurate with the increase of social distance, power and differences in status between interlocutors. With regard to the present study, the aim is to determine whether these social variables have any effect on the choice of request strategies made by the Algerian learners when performing the speech act of request.

Proponents of this theory claim that the politeness theory is universal. Brown and Levinson (1987) believe that culture has a little impact on politeness strategies used by different interactants in different social settings. They claim that the differences in strategies used in different cultures can be 
explained by invoking the power relationship between the addresser and the addressee, the social distance between the two and the rank of each. This claim has been questioned (Kasper, 1990). It is now widely accepted that cultural factors intervene in an individual's choice of politeness strategies and in the social relationships whichactivate face-protective strategies.

Following the above review of the speech act and politeness theories, it is now safe to highlight some of the characteristics of requests as the main concern of the present study. To start with, a request is an illocutionary directive speech act. It is an attempt by the speaker to get the hearer to do something (Searle, 1975).It expresses "the speaker's expectation toward some prospective action... on the part of the hearer" (Blum-Kulka, et al. 1985. p. 114). The different components making up a request are the head act and the supporting moves or the peripheral elements (Blum-Kulka et al., 1989). For a conversation turn to be interpreted as a request, it must at least contain a head act that refers to the request proper. For example, a sentence as "Can/could you open the window?" functions as the request head act. The peripheral elements function as either mitigators or intensifiers of the force of the request (Reiter, 2000). These peripheral elements are of two types, internal and external modifiers.Internal modifiers are devices that occur within the same request head act; external modifiersare devices that "occur in the immediate linguistic context surrounding the request head act, either preceding or following it"(Safont, 2008 p. 65). Request modifiers can be of two types, "downgraders" and "upgraders" (House and Kasper, 1981). The former refer to devices the use of which is meant to soften the illocutionary force of the request, the latter denote devices that intensify the illocutionary force of the request. Linguistically speaking, requests may be realised through imperative, interrogative or declarative sentences in English. In Brown and Levinson's (1987) sense, a request is a face-threatening act (FTA) because it puts some pressure on the hearer to perform the speaker's action. However, depending on the intensity/seriousness of the act, the requester may resort to a number of strategies called politeness strategies. Depending on the strategy adopted by the requester, requests can be either direct or indirect. More important, the choice of a given request strategy largely depends on such parameters like social distance between the requester and the requestee, their relative power, and the size of imposition (Brown and Levinson, 1987).

Now, if one looks closely at the speech act of request, one can easily see that its realisation requires more than a mere mastery and understanding of the forms of language, it calls for knowledge of the target language culture. Ellis (1992, p. 5) contends that a native like realisation of a request, for example, presupposes substantial linguistic and sociolinguistic knowledge. $\mathrm{He}$ pens, "The learner needs to develop a range of linguistic devices and also to learn how to use these in socially appropriate ways". In other words, successful 
communication involves far more than knowledge of the linguistic forms of different speech acts; it requires an understanding of how human communicative interaction is socially organized and culturally patterned. This is because "language use is not chaotic, but patterned in both similar and different ways from the combinatorial organization of the linguistic code itself" (Gumperz, 1982, p.155). Speech acts, therefore, have a high cultural nature and, thereby, their importance in intercultural communication. This importance stems from the fact that their realisation requires the learners not only to possess linguistic competence but socio-cultural competence as well. Sociocultural competence is used here to mean a "speaker's ability to determine whether it is acceptable to perform the speech act at all in the given situation and, if so, to select one or more semantic formulas that would be appropriate in the realization of the given speech act" (Cohen,A. 1996, p.254).

Despite the fact that many scholars claim that speech acts are universal, different studies show that they are realised differently across cultures (see below). Wierzbicka (1985), for example, asserts that speech acts vary in both conceptualisation and verbalisation from one culture to another. Consequently, people rely heavily on their cultural norms in the performance and interpretation of different speech acts. When it comes to learning a foreign language, unawareness of these norms may lead to intercultural pragmatic failure and cause communication breakdowns. Consequently, speakers may resort to transfer of their native culture communication norms. Cross cultural transfer or inter cultural transfer is the subject matter of cross-cultural pragmatics. Its importance is vital with regard to teaching a foreign language as asserted by Rintell-Mitchell (1989, cited in Trosborg 1994: 3) who wrote:

Perhaps the fascination that the study of crosscultural pragmatics holds for language teachers, researchers, and students of linguistics stems from the serious trouble to which pragmatic failure can lead. No "error" of grammar can make a speaker seem so incompetent, so inappropriate, so foreign, as the kind of trouble a learner gets into when he or she does not understand or otherwise disregards a language's rules of use.

The works of Austin and Searle paved the way for further research on speech acts. The Cross-cultural speech act realization project (CCSARP) (Blum-Kulka, House \& Kasper, 1989) is one of the first intercultural studies on speech acts. One of the basic findings of this study is that despite the fact that speech acts have some universal features still their realisation varies across cultures. Speakers from different cultures use different strategies in the realisation of speech acts. It is therefore an imperative, as assumed by the present study, that foreign language learners be aware of the target language 
socio-cultural restrictions on speech acts realisation in order to be pragmatically competent. On the basis of the design and coding schema of this research, other researches including the present one, were carried out. Among these are Holmes (1990) on apology, Cohen \&Olshtain (1993) on complaints and Barron (2003) on requests, to name but a few. The general procedure followed by these studies starts with a search for pragmatic universals, moves towards culture-specific pragmatics, inter-cultural interactional and pragmatic failure, and finally towards implications for language teaching. Their aim was to determine what knowledge, attitudes and skills foreign language learners should possess to be interculturally competent. The interests of these and other researchers centred on the learners' intercultural communicative and sociolinguistic (pragmatic) competence. In sum, they concentrated on crosscultural variables thought to influence the learners' intercultural (pragmatic) competence development. These researchers think that these variables, some of which are summarised below, are of paramount importance in accounting for speech acts realisation within different cultures (Wierzbicka, 1991).

$>$ Cross cultural differences in the realisation of different speech acts in different culture,

$>$ Norms of use, for example politeness norms and strategies in the realisation of certain speech acts,

$>$ Culture-specific rules of use, communication styles such as directness, indirectness and appropriateness.

$>$ Language is not only a tool for describing reality but also for transforming it.

Such variables, and the like, are believed to differ from one culture to another, to reflect different cultural values, or rather different hierarchies of values, to influence ways of speaking and communicative norms and styles that may lead to misunderstanding or communication breakdowns (Wolfson, 1989). The results of these and other researches were applied in different fields and disciplines and have demonstrated the need to assist foreign language learners to not only develop linguistic but also inter-cultural competencies. This field of study has come to be known as intercultural pragmatics. Its main concern lies in the analysis of interaction in which interlocutors do not share common cultural backgrounds, namely the explanation of intercultural (pragmatic) miscommunication.

Intercultural pragmatics as succinctly defined by Kasper (1996, p. 145 ) is perceived as "the study of non-native speakers' use and acquisition of target language pragmatic knowledge" (italics added). One of the basic assumptions of intercultural pragmatics as phrased by Kasper (ibid, p. 156) runs as follows 'the influence exerted by learners' pragmatic knowledge of languages and cultures other than L2 on their comprehension, production, and acquisition of L2 pragmatic information". It is, therefore, believed that in their 
attempts to realise different speech acts in the foreign language, the learners rely heavily on their native language intercultural communicative competence. This phenomenon is referred to in foreign language teaching as pragmatic transfer and occurs when "native procedures and linguistic means of speech act performance are transferred to inter-language communication" (Blum-Kulka, House and Kasper 1989, p.10). Takahashi \& Beebe (1993) held that transfer consists of both cross-linguistic influence and cross-cultural transfer of elements.

Pragmatic transfer can be described either as negative or positive. It is positive when ways of speech acts realisation are similar in both the learners' target and native cultures and are correctly transferred from the native to the target culture.

It is described as negative when the native and target cultures ways of speech acts realisation are different and is usually attributed to "overgeneralization, simplification, reduction of sociolinguistic or sociopragmatic inter-language knowledge" (Trosborg 1994, p. 55). Hence, social and cultural factors which usually affect speech acts realisation are an important source of Socio-pragmatic failure, i.e., the learners' inability to understand what is meant by what is said (Thomas, 1983). More precisely, pragmatic failure refers to the learners' inability to recognise the force of the speaker's utterance.

\subsection{Previous Studies on Requests}

Socio-pragmatic and intercultural pragmatic transfer has been documented in many studies which dealt with how non-native speakers differ from native speakers in interpreting and producing speech acts in the target language. The usual procedure followed consists of collecting data, highlighting the differences between the native and the target cultures in the realisation of different speech acts and an analysis of the different strategies used by the learners is, then, carried out. In these cross-cultural pragmatic studies, speech acts and the politeness maxims have been a rich explanatory source of the data collected.

As a case in point, House and Kasper (1987) used a discourse completion task to locate deviations in the choice of directness levels in five request situations. The study involved German and Danish learners of English. The analysis of the data showed that the learners tended to follow their native language norms in their realisation of the speech act under study. The researchers also noticed that these learners used far more direct imperatives than the native speakers and attributed it to the influence of the learners' native language.

Otcu and Zeyrek (2008) investigated the requests realisation by Turkish learners. Their aim wasto examine the role of language proficiency in request realisation and the way these learners modify their requests. Their study 
involved four groups,two groups of learners of English, one group of native speakers and a third group of native speakers of Turkish. The results showed a strong correlation between the way learners modify their request and their level of proficiency.

\subsection{Methodology \\ 1.2.1. Participants}

The informants of this studyare Master2 students from ConstantineUniversity 1. They are advanced learners of English.At the time of the study, the students'age ranges between 23 and25 years and their mother tongue is mostly Arabic.

\subsubsection{Data for the Study}

The data for the present study consists of learners' emails sentto four of their faculty members during a two-year period (2012/2014). The total number of emailscollected from the teachers amounts to 100.After scrutinising the emails, only emails that include utterances that fulfil the speech act of requesting were considered.As such, 80 emails were selected for the study.More important, the emails were classified following the learners' aims into Requests for Action (request for reference books, request for fixing an appointment) and Requests for Information(request for feedback, request for advice). One important thing to mention is that all emails are anonymous.

\subsubsection{Data for the Study}

The data for the present study consists of learners' emails sentto four of their faculty members during a two-year period (2012/2014). The total number of emailscollected from the teachers amounts to 100.After scrutinising the emails, only emails that include utterances that fulfil the speech act of requesting were considered.As such, 80 emails were selected for the study.More important, the emails were classified following the learners' aims into Requests for Action (request for reference books, request for fixing an appointment) and Requests for Information(request for feedback, request for advice). One important thing to mention is that all emails are anonymous.

\subsubsection{Procedure of Analysis}

At the very outset, itshould be noted thatsome email messages include more than one request item, but only one request per email was selected. A related point to consider is that the social parameters of relative power and social distance across email messages is unchanging. The institutional relationship is lower ranking to higher-ranking. The requester (the learner) islower in status compared to the requestee (the teacher) who is in a position of relative authority.

For a more appropriate analysis of the collected data, only emailsthat include an utterance or a sequence of utterances that contains the realisation of the speech act of requestis considered.The learners' emails are reported with no modification or correction. Prior to the analysis of the various requests included 
in the emails, the head act of each request and the mitigating devices used to soften the imposition force of the head act are identified. The mitigating devicesare then categorisedinto internal and external devices following the CCSARP (Blum-Kulka et al., 1989)with some additions and modifications as thought necessary.Such a division permitted to analyse the head acts in termsof the requester's choice of perspective orientation. The data is then analysed both qualitatively and quantitatively. From a qualitative perspective, the requests are classified according to their request perspective(hearer or speaker oriented, inclusive, or impersonal). From a quantitative perspective, the politeness strategies used in the realisation of the request speech act are analysed in terms of their level of directness/indirectness ranging from the most direct explicit leveltothe nonconventional indirect level following the CCSARP framework developed by Blum-Kulka, House and Kasper (1989). The nine strategy types used within the CCSARP framework adopted for the purposes of this study with examples from the participants' responses are displayedin the table below.

\begin{tabular}{|c|c|c|}
\hline $\begin{array}{l}\text { CCSARP } \\
\text { Directness } \\
\text { Levels }\end{array}$ & Request Strategies & Examples \\
\hline \multirow{5}{*}{$\begin{array}{l}\text { Direct Explicit } \\
\text { Level } \\
\text { (least } \\
\text { ambiguous) }\end{array}$} & $\begin{array}{l}\text { 1. Mood derivable } \\
\text { Utterances in which the grammatical mood of } \\
\text { the verb signals illocutionary force }\end{array}$ & $\begin{array}{l}\text { Please send } \\
\text { me the } \\
\text { books. }\end{array}$ \\
\hline & $\begin{array}{l}\text { 2. Performative } \\
\text { Utterances in which the illocutionary force } \\
\text { is explicitly named }\end{array}$ & $\begin{array}{l}\text { I am asking } \\
\text { you to help } \\
\text { me. }\end{array}$ \\
\hline & $\begin{array}{l}\text { 3. Hedged performatives } \\
\text { Utterances in which the naming of the } \\
\text { illocutionary force is modified by hedging } \\
\text { expressions }\end{array}$ & $\begin{array}{l}\text { I would like } \\
\text { you to tell } \\
\text { me how to } \\
\text { do it. }\end{array}$ \\
\hline & $\begin{array}{l}\text { 4. Obligation statements } \\
\text { Utterances, which state the obligation of the } \\
\text { hearer to carry out the act: }\end{array}$ & $\begin{array}{l}\text { You should } \\
\text { show me } \\
\text { how to do it. }\end{array}$ \\
\hline & $\begin{array}{l}\text { 5. Want statements } \\
\text { Utterances, which state the speaker's desire } \\
\text { that the hearer carries out the act. }\end{array}$ & $\begin{array}{l}\text { I wish you } \\
\text { would give } \\
\text { us more time } \\
\text { to finish. }\end{array}$ \\
\hline
\end{tabular}




\begin{tabular}{|l|l|l|}
\hline $\begin{array}{l}\text { Conventionally } \\
\text { indirect }\end{array}$ & $\begin{array}{l}\text { 1. Suggestory formulae } \\
\text { Utterances that contain a suggestion to do } \\
\text { something }\end{array}$ & $\begin{array}{l}\text { How about } \\
\text { next } \\
\text { Thursday? } \\
\text { (appointment } \\
\text { request) }\end{array}$ \\
\cline { 2 - 3 } & $\begin{array}{l}\text { 2. Query preparatory } \\
\text { Utterances containing reference to } \\
\text { preparatory conditions as conventionalised in } \\
\text { any language: }\end{array}$ & $\begin{array}{l}\text { Could } \\
\text { you/would } \\
\text { you tell me } \\
\text { when can I } \\
\text { meet you? }\end{array}$ \\
\hline $\begin{array}{l}\text { Non- } \\
\text { conventional } \\
\text { indirect } \\
\text { (most } \\
\text { ambiguous) }\end{array}$ & $\begin{array}{l}\text { 1. Strong hints (partialreference to request } \\
\text { goal) }\end{array}$ & $\begin{array}{l}\text { I cannot do } \\
\text { it by myself. }\end{array}$ \\
\cline { 2 - 3 } & Mild hints (no reference to the request \\
proper, context dependent) & $\begin{array}{l}\text { Ido not have } \\
\text { the net at } \\
\text { home. }\end{array}$ \\
\hline
\end{tabular}

Table 1 Analysis Framework (adapted from Blum-Kulka, House and Kasper, 1989).

\subsubsection{Research Questions}

The following questions guided the present study.

1. Does the learners' linguistic proficiency constrain theirrequest strategies?

2. What are the request strategies usedby Master 2 learners of English?

3. Does the learners' culture affecttheir requests strategies?

\subsection{Analysis and Interpretation}

\subsubsection{Request Perspective}

As mentioned earlier, the learners' emails were classifiedinto requests for information and requests for action according to the learners' aims. Following this classification, 48.75 ofthe emails were action oriented and $51.25 \%$ ofthe emails were information oriented. With regard to the speech act perspective adopted by the learners,most of them had a greater tendency toward a hearer-oriented perspective. Thelearners' speech acts in the first placereflect a hearer oriented perspective $(50 \%)$ as in "Could you reschedule another meeting" followed by a speaker orientedperspective (40\%) as in 'if you do not mind, could I know where my weakness is'or.Few learners adopted the inclusive oriented perspective (10\%) as in 'can we now print our dissertation?' and all of them avoided the impersonal oriented perspectiveas in 'Would it be possible topostpone the exam?' (00\%). The learners' request type and perspectives results are displayed in the table below. 


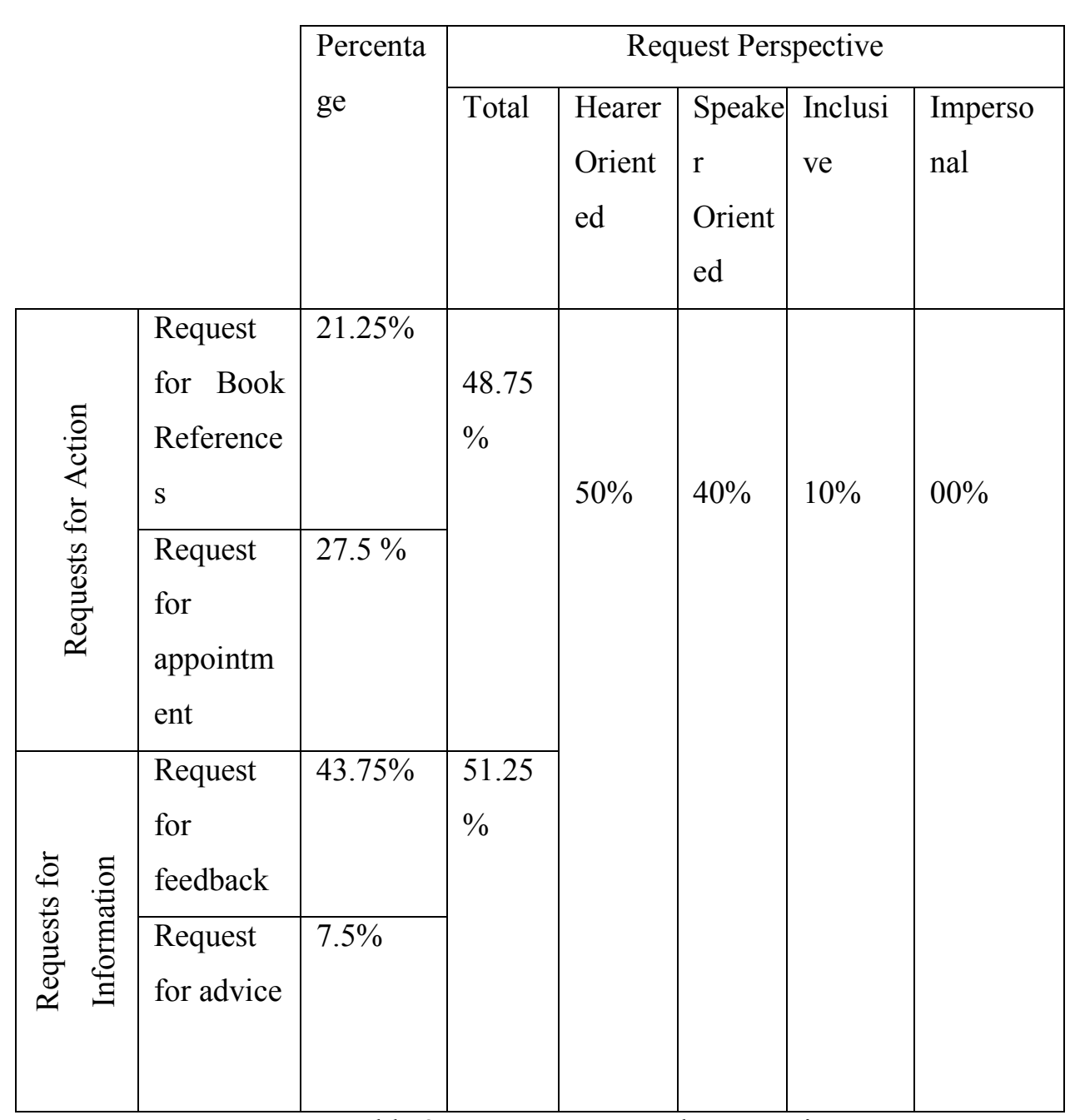

Table 2 Request Types and Perspective

Following Blum-Kulkaet al, (1989), the choice of perspective can either increase or reduce the coerciveness levelofthe illocutionary force of the request speech act.They wrote, "avoidance to name the hearer as actor can reduce the form's level of coerciveness" (1989, p. 19). Accordingly, the learners deviated from what is expected. They failed to comply with the conventions of appropriate linguisticbehaviour that is an indication of pragmatic failure.The first impression one gets is that most of the learners' requests $(50 \%)$ wererather imposing because they did not leave space for alternative choices for the hearer. More importantly, research on requests perspective(Biesenbach-Lucas, 2007) indicates thatthe impersonal and inclusive perspectives of requests using phrases of the type 'would it possible.../Could we have more exercises?'are more positive and therefore more suitableto the interlocutors' status, power and 
roles in the emails.Interestingly, the choice of a hearer-oriented perspectivemay be accounted forlinguistically. The learners have not yet developed greater pragmalinguisticcompetence which enables them to produce utterances with an inclusive or impersonal oriented perspectivewhich require more complex structures.

\subsubsection{Request Strategies}

Following the CCSARP framework, the politeness strategies found in the learners emails were coded into three types namely, direct strategies (DS), conventionally indirect strategies (CIS), and non-conventionally indirect strategies (NIS). The results are displayed in the table below.

\begin{tabular}{|c|c|c|}
\hline \multicolumn{3}{|c|}{ Politeness Request Strategies } \\
\hline Direct & Conventionally Indirect & Non-Conventionally Indirect \\
Strategies & Strategies & Strategies \\
\hline $55.2 \%$ & $40.8 \%$ & $4 . \%$ \\
\hline
\end{tabular}

Table 3Distribution of Politeness Strategies

The above table, whichdisplays the frequency of occurrence of each type of strategy, shows that Direct Strategies were the most preferred with a percentage of $55.2 \%$ followed by Conventionally Indirect Strategies with $40.8 \%$ and the least preferred type is Non-Conventionally Indirect Strategies with $4 \%$.

Following the notion of dominance and obligation that characterise the teacher-learner relationship, the requester (learner) has little right to ask the requestee (teacher) who, in turn, has no obligation to comply with the learner's request. In the words of House (1986, p. 50), in a lower ranking to higherranking situation, there is a "relatively low obligation for the addressee to comply and equally low rights on the part of the requester, thus resulting in greater difficulty in performing the request". More important, because the teacher-learner social distance is high, the use of indirectness is contextually expected.

Following the results displayed in the above table, one possible reason why the learners phrased their requests using direct strategies is their reliance on their native language/culture socio-pragmatic and pragma-linguistic knowledge. They seem to have evaluated the situational factors involved in email writing on the basis oftheir native language sociopragmatic norms rather than those of the English language culture. The use of more direct and less indirect requestive strategies is a clear indication that the learners have'different perceptions of what constitutes appropriate linguistic behaviour' (Thomas, 1983, p. 99). Their emails may thus be inappropriate given the high imposition of the situation. Even worse, the learners were little concerned with the need to secure a way to opt out of their request (Weizman, 1993).

\subsubsection{Request Sub-Strategies}


With regard to the request sub strategies used by the learners, the analysis of the collected emails showed that the learners used requestsub strategies with varying degrees. As displayed in table two below, 125 strategies were identified. The general results indicate that there was an overall preference on the part of the participants for directness. Most learners opted for direct (hearer oriented) strategies. In this respect, mood derivable strategies were the most often used with $24 \%$.The other strategies used are as follows: a)Performatives(12.8\%), (b) Want statements (9.6\%) and (c) Hedged performatives $(8.8 \%)$. Obligation statements $(00 \%)$ were totally absent from the data of this study.Conventionally indirect strategies were realized through query-preparatory and suggestory utterances with a percentage of $36 \%$ and $4.8 \%$ respectively.Non-conventionally indirect strategies were used very scarcely. They were found in $4 \%$ of the learners' emails. The following Table gives more details.

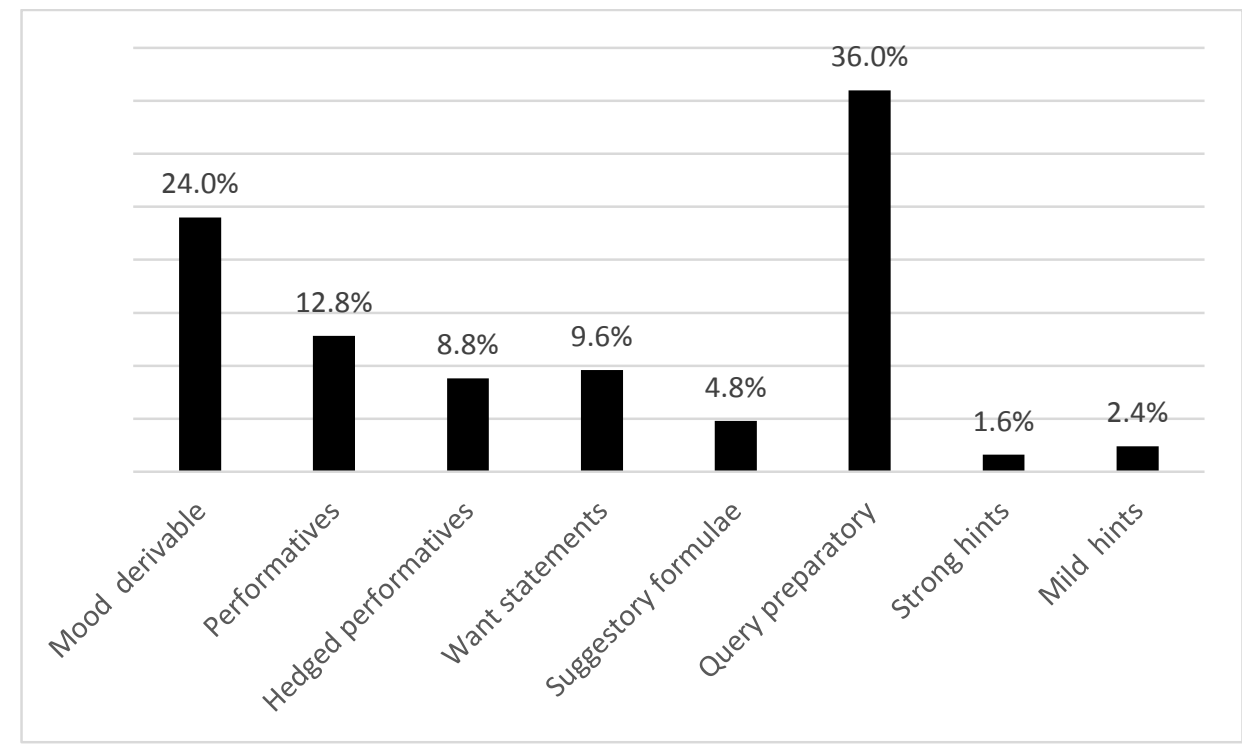

Table 4Politeness Request Sub-Strategies

The above results show that the significant use of direct strategies gives teachers no choice but to comply with the learners' requests. Pragmatically speaking, most of the participants' emails seem to be institutionally inappropriate.According to Bloch (1996), this type of email may not be appropriate in institutional talk that usually requires a high degree of politeness.Following the same line of reasoning, Hartford and BardoviHarlig(1996, p. 59) believe that "students do not have the institutional status to issue directives to faculty, and the use of this form puts them seriously out-of- 
status .... Such noncongruent acts in institutional talk require a fairly high level of mitigation". However, the overuseof direct strategies does not mean that the learners are not polite because they usedsome mitigating devices to soften the imposition of their requests. Similar studies (Wierzbicka 2003, Al-Marrani and Sazalie(2010) reached theconclusion thatdirectness in some cultures is not commensurate with impoliteness.In the case of the participants in this study, directnessis a way of expressing connectedness, familiarity, friendship and affiliation.Typical examples of the direct strategies used are mood derivable imperative constructions of the type'Please + Imperative' and 'Want Statements' as exemplified by the following.

a. please tell us when will you come to the university

b. please Dr. ....... tell me when can I find you at university to bring you the dissertation

c. Please Sir, e-mail me if you have something

d. Iwant to know if anyone of your students had sent you the papers

e. I want you to see them.

The overuse of imperative utterances by the learners is a clear indication that they were unable to use the appropriate pragmalinguistic means to realise a request. Their pragmatic competence is insufficient. Examples (a) and (b) above, which are instances of the imperatives used in the emails, show that the learners were aware of the imposition of their requests and consequently they resorted to the use of the softener "please" to mitigatethe force of the imperatives and therebycomply with institutional talk.Following Blum-Kulka et al. (1989) politeness is generally positively correlated with indirectness in British culture.In the words of Brown and Levinson (1987, p. 17), "direct requests appear to be inherently impolite and face-threatening because they intrude in the addressee's territory". Accordingly, the above sentences are rather unexpected for they do not give any option to the teacher not to act and thus minimize the negative face threat.However, in the learners' culture the use of direct strategies does not reflect a lack of concern for the hearer's face. Contrary to what is claimed by Brown and Levinson's politeness theory, in the learners' culture directness is appreciated and is associated with honesty.

More important,out of the 45query preparatory strategy utterances used,the softener "please" occurs in initial position in twenty of them. This indicates that the influence of the learners' L1 is at work. This is so because English and Arabic differ in positioning the politeness marker within the utterance. The politeness markers in Algerian Arabic (tiichmin fadlik) usually occur in head act initial position whereas English shows a strong preference for using "please" outside the head act, utterance final position.

In addition, many studies on request realisation (Francis, 1997; Harlow, 1990; Parent, 2002)concluded that there is a correlation between complexity/simplicity of request strategies and the learners' level of language 
proficiency. Learners with a high language proficiency level tend to usemore complex request strategies (conventionally and non-conventionally indirect strategies) and learners with a low language proficiency level tend to use simple request strategies (direct strategies). In relation to the learners involved in the present study, most of them used direct strategies (55.2\%)in the imperative form and they restrainedly used conventionally indirect strategies (35.08 \%). More precisely, the learners have shown a preference to conventionally indirect strategies conveyed by only the query preparatory substrategy more than any other one. In addition, very few of them used nonconventionally indirect strategies (4\%). Thus, the overuse of direct strategies can be explained by the low linguistic proficiency level of the learners. They are not yet sufficiently competent to use a wide variety of strategies. They may be aware of the appropriate pragmatic strategy to be used in a lower ranking to a higher-ranking context, but they do not know how to realize them due to their limited linguistic knowledge (Takahashi \& Beebe, 1993).

In addition, non-conventional indirect (most ambiguous) strategies were the least preferred strategy in the learners' emails. Because the realisation of non-conventional indirect strategies requires structures that are more complex, the learners chose not to use them. This is another indication that the learners have not yet developed paragmalinguisticcompetence that enables them to use this type of strategies on appropriate occasions.

\subsubsection{Internal Modification Analysis}

According to Blum-Kulka, House, \& Kasper (1989), internal modifiers refer to elements that occur with the request head act but do not alter its meaning. Their use is meantto either soften (downgraders) or aggravate (upgraders) the imposition of aspeech act.Internal modifiers are usually divided into lexical/phrasaldowngraders, syntactic downgraders and internal upgraders. With regard to the present study, the following table displays the internal request modification devices used by the learners. 


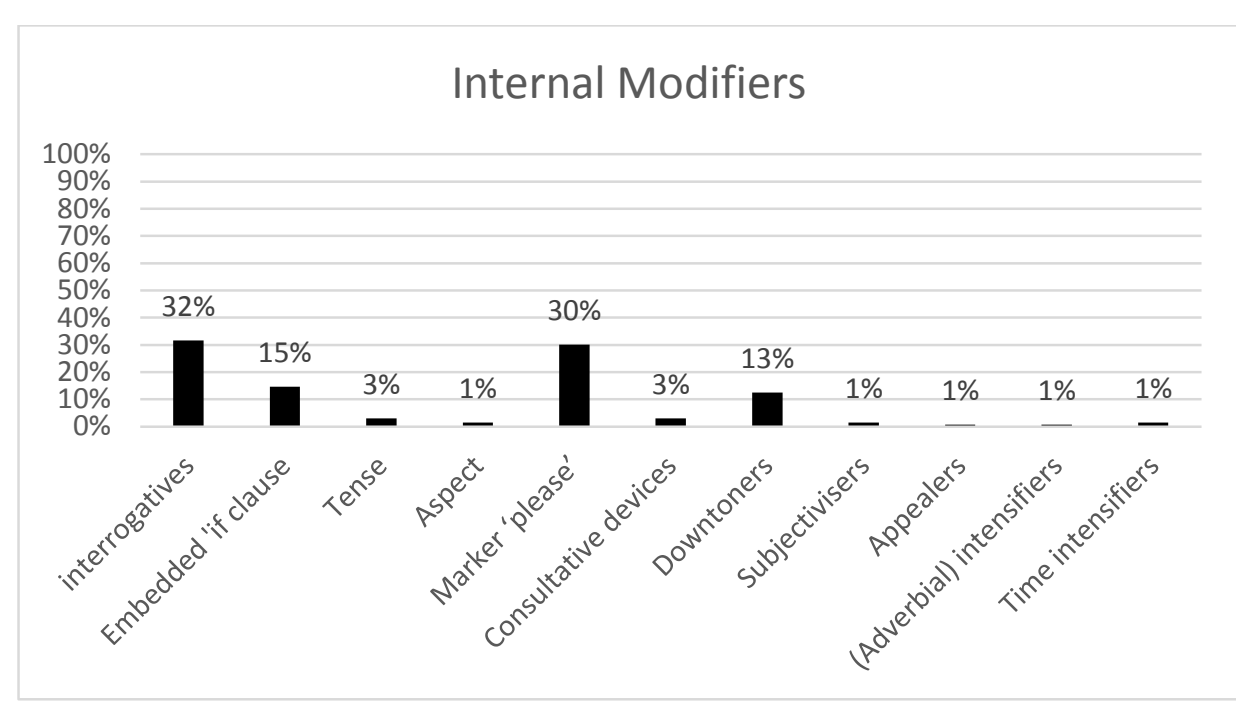

Table 5 Types of Internal Modification Devices

As displayed in the above table, the learners made use of all modification devices exceptnegation of a preparatory condition and understaters/hedges. With regard to lexical/phrasaldowngraders, the most often used device is the politeness marker "please" with 30\%.Downtoners were also used by the learners although to a lesser extent with $13 \%$.Consultative devices occurred in the participants' responses extremely rarely with $3 \%$.Other strategies in the form of subjectivisers, appealers, time intensifiers and adverbial intensifiers were very sparingly use with $1 \%$ each. The second type ofinternal modification devices used are syntactic downgraders. The most often used are interrogativeswith $32 \%$ followed by embedded if clauses with $15 \%$.The other devices, tense andaspect occurred in $1 \%$ and $3 \%$ of the learners emails respectively. The use of the above mentioned internal modification devices indicates the learners were aware of both the imposition of their requests and thestatus and power differenceswhen addressing their teachers.

As far as lexical/phrasal downgraders are concerned, the learners resorted to the use of the politeness marker "please" to mitigate the force of their requests.However, this device is oddly combined with the use of verbs in the imperative form as shown in the following.

a. please tell us when will you come to the university

b. please Dr. ..... tell me when can I find you at university to bring you the dissertation

c. Please Sir , e-mail me if you have something

$d$. sir, please answer my calls or join me on the net whenever possible.

e. Please read it and, of course I'm welcoming any of your suggestions. 
The above examplesexpress direct requests using the imperative strategy modified by the lexical/phrasal downgrader "please" as a politeness marker. As, was previously mentioned, the learners overused this device (42\%), something which mirrors findings fromFearch and Kasper (1989), House (1989) and Barron (2003).These studies concluded that this politeness marker had a high frequency of occurrence because of its "double function as illocutionary force indicator and transparent mitigator" (Faerch and Kasper, 1989, p.232).Another possible interpretation is that the learners did not use the word "please" as a politeness marker but as a lexical device to mark the utterance as a request.This in turn can be interpreted to meanthat the learners lack pragmalinguistic competence. With regard to the learners' language proficiency, the use of 'please' does not necessarily imply knowledge of subordination or of complex syntactic structures required in the use of other mitigating devices than imperatives.

The other lexical/phrasal downgraders used are downtoners. These are propositional and sentential devices (Holoch, 2009) used to soften the impact of the requests. As displayed in table 5 above, the learners' reliance on the use of 'Downtoners' $(18 \%)$ was not significant.The following are some of the learners' examples.

a. i just wanted to asked whether you finished correcting my thesis or not yet

b. $i$ just thought maybe you sent me something and i didn't receive it!

c. I just wanted to know if this article is a reliable source to be used in my thesis.

d. I just wanted to discuss these issues with you

The learners also used consultative devices tomodify the illocutionary force of their requests by involving teachersand checkingtheir opinion (House and Kasper 1987). However, the number of consultative devices was very small $(4 \%)$.

As mentioned above,syntacticdowngraders were present in the data of this study. Among the syntactic downgraders used by the learners are interrogative constructions, embedded if clauses, tense and aspect.Among the different interrogative constructions used by the learners, ability questions with the modal verbs can/could/would constitute the most frequent request type in the data of this study. Interestingly, most of these constructions are formulated in the secondperson; very few ( 6 out of 43 ) were formulated in the first person. Therefore, most of them reflect the hearer's perspective (Blum-Kulka et al. 1989) which makes them less polite because the learnersdid not omit to refer to the cost to hearer (leech, 1983). More important, most of these constructions were formulated in the past tense. 
As displayed in table 4 above, the use of upgraders (adverbial intensifiers and time intensifiers) in the participants' English e-mail requests was just 3\%. This shows that the participants made very little use of intensifiers/upgraders in order to increase the urgency and coerciveness of their requests.Considering the status of the learners and the degree of their requests coerciveness, they might be consideredpoliteLazarescu (2013). With regard to Subjectivisers and Appealers, the learners used them very scarcely. They are found in only $1 \%$ of the emails.

\subsubsection{External Modification}

In addition to internal modification, the learners also used external modification to soften or emphasize the force of their request. The following table gives details of the various supportive moves used by the learners.

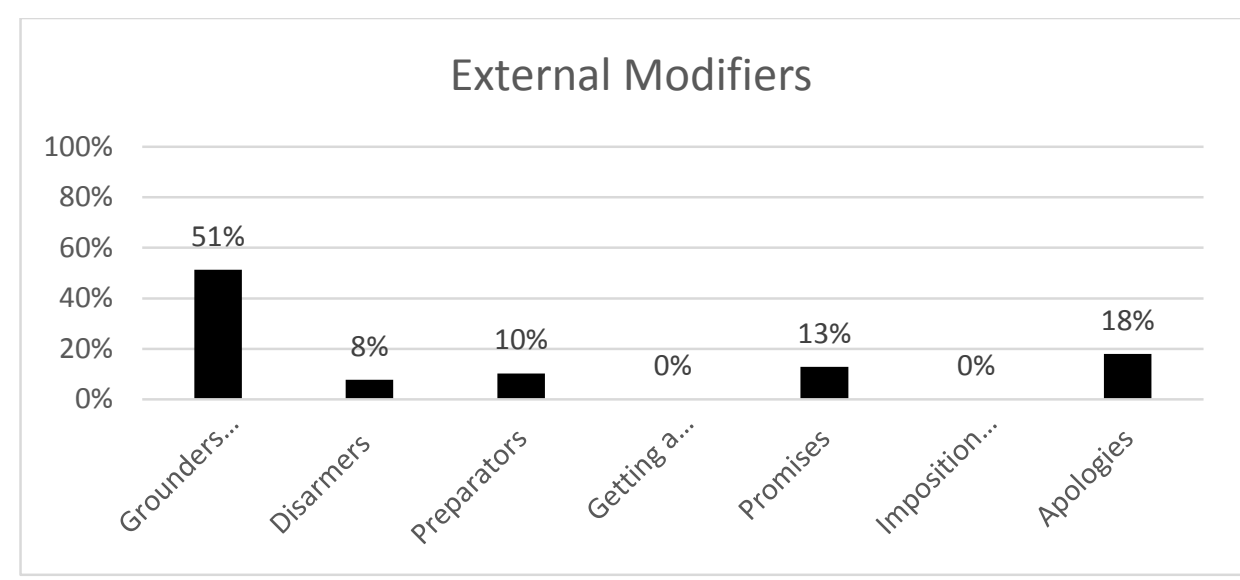

Table 6 Internal Modifiers

The firstmodifierexternal to the head act contributing to the politeness value of the learners' linguistic action is grounders. Grounderssupply a reason for making the request and reduce the threat to the hearer's face (Faerch and Kasper 1989). They are meant to get the teachers' positive response (Brown and Levinson, 1978). Compared to other external modifiers, grounders were the most often used with a percentage of $51 \%$.This finding is in line with the findings from other studies ((Blum-Kulka\&Olshtain, 1986 House \& Kasper, 1987). Take the following.

a. Could you please inform me when you receive my assignment? I am afraid you might not receive it due to some technical error.

b. $i$ know that you supervise many others, i just thought may be you sent me something and i didn't receive it! 
c. Prof $X$ asked us to send the abstracts to our supervisors before sending them to her. So, would you please have a look on it before the dead line- 14 February.

d. Good evening siryou asked me to add some suggestions would you please take a look!! and thank you .

A close examination of the grounders used by the learners reveals that there is some degree of familiarity between the teachers and the learners. This has increased the learners' right to issue the request and expectcompliance.The excessive use of grounders $(51 \%)$ is a clear indication that the learners tried to compensate for their linguistic and sociopragmatic insecurity or they drew on the use of grounders in their native language.

Another external modifier used by the learners is apology. The learners had recourse to this device because they "felt therequest act was not adequately modified to extend a level of politeness that theyexpected" (Pan, 2012, p.148). Within the present data, apologies were used in $18 \%$ of the emails. The way learners extend their apologies is demonstrated in thefollowing emails.

a. I'm sorry I know I'm late..........

b. I am so sorry doctor to disturb you, but since i got the worst mark, could you give me any suggestion or advices that can help me to improve my skills in answering the questions.

c. sorry to intrude. Would you please inquire about the subjects proposed at the university of Annaba(l'écoledoctorale)? I cannot find anything on the net.

d. Could you tell me when you're free to meet you at the university, please?Sorry to bother you.

As shown by the above examples, the apology expressions used aremeant tosoften the face-threatening act of request and manage the face rapportas required by situations that involve the social factors of power and distance. More important, the participants have drawn on the norms of their language and culture by apologizing prior to requesting(Allami and Naeimi (2011).

In order to boost thepossibility of the teachers'agreement with their request, the learners committed themselves to fulfil certain jobs upon accomplishment of therequested act. This modifier occurred in $13 \%$ of the emails. The aim is to soften the impositive forceof their requests. However, this shows that the learners are not aware of the social and situational conventions that govern request realization in English speaking communities. The following are examples of promises the learners made.

a. 'Could you give me an extension? I promise I'll have it ready for next week.

b. Excuse me sir, I have not finished yet. I'll bring the whole dissertation the next time we meet. 
The other two external modifiers used by the learners, though with scarcity, arepreparators' and disarmers. The results of the present study indicate that 'preparators' and disarmers occurred in $10 \%$ and $8 \%$ of the emails respectively. It should be noted that both of them occur in head act initial position. The use of this type of modifiers shows that the learners were aware of their requests imposition on the teachers. Typical constructions found in the data are:

a. I know u $r$ busy so I really don'twanna bother $u$, if $\mathrm{u}$ give me your feedback then I try to do it again.

b. I know that you are too busyand have spent your time for my thesis.

c. May I ask you a favour.....

The linguistic repertoire, as demonstrated by the above examples, used to modify the request externally is simple and limited to structures of the type "I know that you are too busy". This shows that the learners' linguistic proficiency level constrains the structure of the strategies they use to soften their requests.

\section{Conclusion}

This study has shown that the learners' pragmatic knowledge significantly influences theirproduction of pragmatic performance in English. More important, the learners transferred culture-specific patterns from their culture social practices into the realisation of requests in English. The findings also indicated that the learners' linguistic proficiency and sociopragmatic and pragmalinguistic knowledge constrain both the request perspective and the use of modification devices. Put differently, there is evidence of correlation between EFL learners' level of language proficiency and type of requesting.Finally yet importantly, the present examined emails exhibit culturespecific preferences forpoliteness strategies.Directness in the realisation of requests does not necessarily imply impoliteness. Direct strategies used by the learners are culture dependent and cannot be considered impolite. They rather express closeness and affiliation.

\section{Reference List}

Barron, Anne (2003). Acquisition in interlanguage pragmatics: Learning how to do things with words in a study abroad context. Amsterdam: John Benjamins.

Biesenbach-Lucas S (2007) Students writing emails to faculty: An examination of e-politeness among native and non-native speakers of English. Language Learning and Technology 11(2): 59-81

Blum-Kulka, S., \&Olshtain, E. (1986). Too many words: Length of utterance and pragmatic failure. Journal of Pragmatics, 8, 47-61. 
Blum-Kulka, Shoshana, Juliane House, and Gabriele Kasper. (eds.) 1989. Cross-cultural pragmatics: Requests and apologies. Norwood: Ablex Publishing

Brown, P. and Levinson, S. 1987. Politeness: Some Universals in Language Usage. Cambridge: Cambridge University Press.

Brown, P., \& Levinson, S. (1987). Politeness: Some universals in language usage. England: Cambridge University Press.

Cohen, A.D. (1996). Developing the ability to perform speech acts. Studies in Second Language Acquisition, 18, 253-267.

Crystal, D. (1993). An Encyclopaedic Dictionary of Language and Languages. Oxford: Blackwell.

Ellis, R. (1992). Learning to communicate in the classroom: A study of two language learners' requests. Studies in Second Language Acquisition, 14, $1-23$.

Faerch, C. and Kasper, K. (1989). Internal and external modification in interlanguage request realisation. In S. Blum-Kulka, J. House and G. Kasper (Eds.), Cross-cultural Pragmatics, (pp. 1-34). Norwood, NJ: Ablex.

Faerch, C., \& Kasper, G. (1989). Internal and external modification in interlanguage request realization. In S. Blum-Kulka, J. House, \& G. Kasper (Eds.), Cross-cultural pragmatics (pp. 221-247). Norwood, NJ: Ablex.

Francis, C. (1997). Talk to me! The development of request strategies in nonnative speakers of English. Working Papers in Educational Linguistics, 13(2), 23-40.

Goffman, E. ( 1959). The presentation of self in everyday life. New York: Doubleday.

Gumperz, J. J. (1982). Discourse strategies. Cambridge: Cambridge University Press.

Harlow, L. L. (1990). Do they mean what they say? Sociopragmatic competence and second language learners. The Modern Language Journal, 74, 328-349.

House, J., \&Kasper, G. (1981). Politeness markers in English and German. In F. Coulmas (Ed.), Conversational routine (pp. 157-185). The Hague: Mouton de Gruyter.

House, J., \& Kasper, G. (1987). Interlanguage pragmatics: Requesting in a foreign language. In W. Lorscher\& R. Schulze (Eds.), Perspectives on language inperformance (pp. 1250-1288). West Germany: Narr, Tubingen.

House, Juliane (1989). Politeness in English and German: the functions of please and bitte. In Cross-cultural pragmatics: Requests and apologies, 
Shoshana Blum- Kulka, Juliane House, and Gabriele Kasper (eds.), 96119. Norwood, NJ: Ablex.

Hymes, D. H. 1971. Competence and performance in linguistic theory, in Huxley, R. and Ingram, E. (eds.), Language Acquisition: Models and Methods. London: Academic Press.

Kasper, G. (1990). Linguistic politeness: current research issues. Journal of Pragmatics, 14, 193-218

Kasper, G. (1992). Pragmatic transfer. Studies in Second Language Acquisition $8,3,203 \sim 231$.

Lazarescu, R. C. (2013). Can you upload as soon as you can please? A study of university student requests by e-mail in English medium instruction (Doctoral dissertation).

Leech, G. 1983. Principles of pragmatics. London: Longman.

Olshtain, E. and Cohen A. W. (1983). Apology: A speech-act set, in Wolfson, N. and Judd, E. (eds.), Sociolinguistics and language acquisition. (pp. 18-35). Cambridge, MA: Newbury House.

Otcu, B. \&Zeyrek, D. (2006). Requesting in L2: Pragmatic development of Turkish learners of English. Proceedings of the 31st international LAUD symposium. Intercultural pragmatics, linguistics, social and cognitive approaches. Landau, Germany: Universität Duisburg-Essen.

Pan, P. C. 2012. Interlanguage requests in institutional e-mail discourse: A study in Hong Kong. Interlanguage request modification. Eds. M. Economidou- Kogetsidis and H. Woodfield. Amsterdam: John Benjamins. 119-162.

Parent, M. P. (2002). The production of requests by Catalan learners of English: situational and proficiency level effects. Atlantis, 2, 147-168.

Safont, M. P. (2008). The speech act of requesting. In E. Alcon (ed.). Learning how to request in an instructed languages learning context. Bern: Peter Lang, $41-90$.

Searle, J. R. (1975). Indirect speech act, in Cole, P. and Morgan , J. (ed.), Syntax and semantics: Speech acts.( pp. 59-82 ).New York: Academic Press.

Searle, J. R. (1969). Speech acts: An essay in the philosophy of language. Cambridge: Cambridge University Press.

Takahashi, T., \& Beebe, L. M. (1993). Cross-linguistic influence in the speech act of correction. In G. Kasper \& S. Blum-Kulka (Eds.), Interlanguage Pragmatic. New York: Oxford University Press.

Thomas, J. (1983). Cross-cultural pragmatic failure. Applied Linguistics, 4(2), 91-122.

Thomas, J. (1995). Meaning in Interaction: An Introduction to Pragmatics. New York: Longman. 
Trosborg, A. (1994). Interlanguage pragmatics - Requests, complaints and apologies. Berlin: Walter de Gruyter\& Co.

Weizman, Elda (1993) Interlanguage requestive hints. In Interlanguage Pragmatics, Gabriele Kasper and Shoshana Blum-Kulka (eds.), 123 137. Oxford UniversityPress.

Wierzbicka, A. (1991). Cross-cultural pragmatics: The semantics of human interaction. Berlin: Mouton de Gruyter.

Wierzbicka, A. (1985). Different culture, different languages, different speech acts. Journal of Pragmatics, 9, 145-78

Wolfson, N. (1989). Perspectives: Sociolinguistics and TESOL. New York: Newbury House Publishers

Yule, G. (1996). Pragmatics, in Widdowson, H.G. (ed.), Oxford introductions to language study. Oxford UniversityPress. 